\title{
Zika virus infection in a traveller returning to Europe from Brazil, March 2015
}

L Zammarchi' ${ }^{1}$ D Tappe ${ }^{2}$, C Fortuna 3 , M E Remoli³, S Günther², G Venturi3 ${ }^{3}$ A Bartoloni (alessandro.bartoloni@unifi.it) ${ }^{1}$, J SchmidtChanasit $^{2}$

1. Clinica Malattie Infettive, Dipartimento di Medicina Sperimentale e Clinica, Università Degli Studi di Firenze, Florence, Italy

2. Bernhard Nocht Institute for Tropical Medicine, WHO Collaborating Centre for Arbovirus and Haemorrhagic Fever Reference and Research, National Reference Centre for Tropical Infectious Diseases, Hamburg, Germany

3. Department of Infectious, Parasitic and Immune-Mediate Diseases, Istituto Superiore di Sanità, Rome, Italy

Citation style for this article:

Zammarchi L, Tappe D, Fortuna C, Remoli ME, Günther S, Venturi G, Bartoloni A, Schmidt-Chanasit J. Zika virus infection in a traveller returning to Europe from Brazil, March 2015. Euro Surveill. 2015;20(23):pii=21153. Available online: http://www.eurosurveillance.org/ViewArticle.aspx?Articleld=21153

We report a case of laboratory-confirmed Zika virus infection imported into Europe from the Americas. The patient developed fever, rash, and oedema of hands and feet after returning to Italy from Brazil in late March 2015. The case highlights that, together with chikungunya virus and dengue virus, three major arboviruses are now co-circulating in Brazil. These arboviruses represent a burden for the healthcare systems in Brazil and other countries where competent mosquito vectors are present.

\section{Case presentation}

A male Italian traveller in his early 6os presented to the Infectious and Tropical Diseases Unit, Azienda Ospedaliero Universitaria Careggi, Florence (Italy), four days after his return from a 12-day holiday in Salvador de Bahia, Brazil at the end of March 2015. The patient had a four-day history of confluent slightly-pruritic erythematous rash, diffused on the face, trunk, arms, and legs, accompanied by fever (maximum temperature $38{ }^{\circ} \mathrm{C}$ ), conjunctivitis, general weakness, and painful oedema of both hands and feet. Blood tests revealed a normal white blood cell count $(6,180$ cells $/ \mu \mathrm{L}$; reference: $4,000-10,000 / \mu \mathrm{L}$ ) with normal differential count, but some activated lymphocytes, thrombocytopenia (112,000/ $\mu \mathrm{L}$; reference: 140,000-440,000/ $\mu \mathrm{L}$ ) and slightly elevated C-reactive protein $(10 \mathrm{mg} / \mathrm{L}$, reference: $<9 \mathrm{mg} / \mathrm{L}$ ). Serum transaminases and creatinine were normal. Because of the clinical presentation and the travel history, a viral infection was suspected, and patient serum was tested for antibodies against chikungunya virus (CHIKV), dengue virus (DENV), Zika virus (ZIKV), Yellow fever virus, West Nile virus, Japanese encephalitis virus, Parvovirus B19, human herpes virus 6 (HHV6), and HIV [1]. The serum sample taken four days after symptom onset showed a positive result for anti-ZIKV-IgM and -IgG antibodies, suggesting an acute or recent ZIKV-infection. Results of the serological tests for the other viruses tested were negative (Table). A follow up sample, taken 26 days after symptoms onset, showed a threefold increase of the anti-ZIKV-IgM and -IgG antibody titres (Table). In addition, a low-titre DENV IgG was now observed (Table), most likely representing a serological cross-reaction of the anti-ZIKV-IgG antibodies (Table). ZIKV-specific realtime reverse transcription-PCR [1] was negative from both samples. Generic flavivirus and alphavirus RT-PCR [1] were also negative. The presence of ZIKV-specific neutralising antibodies in the second serum sample was confirmed by a virus neutralisation assay (Table). The patient was discharged, managed and followed-up in the outpatient department. The patient was recommended symptomatic treatment with paracetamol. The symptoms rapidly resolved in the following week (fever and rash lasted for only four days).

\section{Background}

ZIKV is an arbovirus belonging to the flavivirus genus that was first isolated from a rhesus monkey in the Zika forest in Uganda [2]. It is transmitted by different species of Aedes mosquitoes. Clinical manifestations of ZIKV infection are very similar to those of DENV and CHIKV infections, but usually milder [3]. Human infections have been documented in several African and south-eastern Asian countries [4]. ZIKV was responsible for several outbreaks on islands in the Pacific Ocean, such as Yap Island (Federated States of Micronesia in 2007 [4]) and more recently in French Polynesia, New Caledonia, Easter Island and the Cook Islands in 2013 [5,6]. In several non-endemic countries including Japan, Germany, Italy, Canada, Australia and the United States (US), the infection has been diagnosed in returning travellers $[1,7-11]$.

ZIKV infections have recently been reported in Brazil, where the virus has probably been circulating since 2014 [12]. So far, 16 cases have been confirmed in accordance to the Ministry of Health of Brazil [13].The emergence of ZIKV in Brazil is of concern since Brazil is the country with the highest number of DENV infections 
TABLE

Serological test results and virological data of a case of Zika virus infection imported from Brazil into Italy, March 2015

\begin{tabular}{|c|c|c|}
\hline \multirow{2}{*}{$\begin{array}{l}\text { Antibody or antigen } \\
\text { tested }\end{array}$} & \multicolumn{2}{|c|}{$\begin{array}{l}\text { Serum samples taken after symptom onset } \\
\text { (days) }\end{array}$} \\
\hline & 4 & 26 \\
\hline Anti-ZIKV-IgGa & $1: 160$ & $1: 1,280$ \\
\hline Anti-ZIKV-IgMa & $1: 160$ & $1: 1,280$ \\
\hline ZIKV NAb & ND & $1: 640$ \\
\hline Anti-DENV-IgG ${ }^{a}$ & $\langle 1: 20$ & $1: 20$ \\
\hline Anti-DENV-IgMa & $\langle 1: 20$ & $\langle 1: 20$ \\
\hline DENV-2 NAb ${ }^{b}$ & ND & $\langle 1: 20$ \\
\hline DENV-4 NAb ${ }^{b}$ & ND & $<1: 20$ \\
\hline DENV NS1 ${ }^{c}$ & $\begin{array}{c}\text { Negative } \\
\text { (o.1 arbitrary units) }\end{array}$ & $\begin{array}{c}\text { Negative } \\
\text { (o.1 arbitrary units) }\end{array}$ \\
\hline Anti-JEV-IgGa & $<1: 20$ & $<1: 20$ \\
\hline Anti-JEV-IgM ${ }^{a}$ & $\langle 1: 20$ & $\langle 1: 20$ \\
\hline Anti-WNV-IgGa & $\langle 1: 20$ & $\langle 1: 20$ \\
\hline Anti-WNV-IgMa & $\langle 1: 20$ & $\langle 1: 20$ \\
\hline Anti-YFV-IgGa & $\langle 1: 20$ & $\langle 1: 20$ \\
\hline Anti-YFV-IgM ${ }^{a}$ & $\langle 1: 20$ & $\langle 1: 20$ \\
\hline Anti-CHIKV-IgGa & $\langle 1: 20$ & $\langle 1: 20$ \\
\hline Anti-CHIKV-IgMa & $\langle 1: 20$ & $\langle 1: 20$ \\
\hline
\end{tabular}

CHIKV: chikungunya virus; DENV: dengue virus; DENV-2: dengue virus serotype 2; DENV-4: dengue virus serotype 4; JEV: Japanese encephalitis virus; NAb: neutralising antibodies; ND: not done; NS1: nonstructural protein-1; WNV: West Nile virus; YFV: yellow fever virus; ZIKV: Zika virus.

a Indirect immunofluorescence assay (IIFA) titres $<1: 20$ for serum were considered negative [1].

b Virus neutralisation test (VNT) titres «1:20 for serum were considered negative [1].

SD BIOLINE Dengue Duo NS1 Ag + Ab Combo and Bio-Rad Platelia Dengue NS1 Ag.

world-wide [14]. Moreover, CHIKV has been introduced to South America as well with more than one million of cases diagnosed since 2013 to date [15].

\section{Discussion and conclusions}

The ongoing outbreak of now two major mosquitoborne infections in addition to endemic DENV infections has the potential of posing a serious threat to local and supra-national South American healthcare systems, as observed in the Pacific region in recent years [16].

In endemic areas, but also in the setting of travel medicine, ZIKV infection represents both a clinical and diagnostic challenge since the symptoms are very similar to other arboviral diseases, no specific commercial serological tests are available, and cross-reactive DENV serology (IgG or IgM) during ZIKV infection has been described in previously reported cases [11] which may lead to incorrect diagnoses. Recently, neurological complications possibly related to coinfections or sequential infections with dengue virus have been reported in French Polynesia [17].The European Centre for Disease Prevention and Control (ECDC) published a Rapid Risk
Assessment on ZIKV in the Americas on 25 May 2015, with the aim of increasing awareness and enhancing vigilance towards the detection of imported cases of ZIKV infection in Europe [18]. This case is, to the best of our knowledge, the first laboratory-confirmed case of a ZIKV infection acquired in the Americas and imported into Europe. The patient had returned to Italy, his home country, where Aedes albopictus, a potential competent vector, is widely distributed. Considering the extensive airline travel between Latin America and other parts of the world where the viruses have not yet been established, but competent vectors are present, such as southern Europe and the southern part of the US, the surveillance systems have to be aware of the appearance of ZIKV in Brazil to avoid further dissemination of the disease. In order to prevent seeding of ZIKV into local mosquito populations, as it happened for CHIKV in Italy in 2007 and in France in 2010 and $2014[19,20,21]$, screening of febrile returning travellers for arboviral infections, especially in the summer months, is highly advised.

\section{Acknowledgments}

We thank Mathis Petersen (Hamburg), Birgit Huesing (Hamburg), Sabine Koehler (Hamburg), and Eleonora Benedetti (Rome) for excellent technical assistance. We thank Giovanni Rezza (Rome) for revising the manuscript.

\section{Conflict of interest}

None declared.

\section{Authors' contributions}

Wrote the manuscript: LZ, DT, JSC, GV; performed laboratory investigations: DT, CF, MER, JSC, GV, SG; revised the manuscript: $A B$, JSC; managed the patient: LZ.

\section{References}

1. Tappe D, Rissland J, Gabriel M, Emmerich P, Gunther S, Held G, et al. First case of laboratory-confirmed Zika virus infection imported into Europe, November 2013. Euro Surveill. 2014;19(4):20685. PMID:24507467

2. Dick GW, Kitchen SF, Haddow AJ. Zika virus. I. Isolations and serological specificity. Trans R Soc Trop Med Hyg. 1952;46(5):509-20. http://dx.doi.org/10.1016/00359203(52)90042-4 PMID:12995440

3. Duffy MR, Chen TH, Hancock WT, Powers AM, Kool JL, Lanciotti RS, et al. Zika virus outbreak on Yap Island, Federated States of Micronesia. N Engl J Med. 2009;360(24):2536-43. http:// dx.doi.org/10.1056/NEJMoao805715 PMID:19516034

4. Hayes EB. Zika virus outside Africa. Emerg Infect Dis. 2009;15(9):1347-50. http://dx.doi.org/10.3201/eid1509.090442 PMID:19788800

5. ProMED-mail. Zika virus - Pacific (06): French Polynesia, New Caledonia. 2014. Archive Number: 20140303.2309965.

6. ProMED-mail from HealthMap Alerts. ZIKA VIRUS - PACIFIC (09). Promed mail 2014,Archive Number: 20140328.2365267. Available at: http://www.promedmail.org/direct. php?id=2365267.

7. Kutsuna S, Kato Y, Takasaki T, Moi M, Kotaki A, Uemura H, et al. Two cases of Zika fever imported from French Polynesia to Japan, December 2013 to January 2014 [corrected]. Euro Surveill. 2014;19(4):20683. PMID:24507466

8. ProMED-mail. Zika virus - Canada ex Thailand. Archive Number: 20130529.1744108. Available from: http://www.promedmail. org/direct.php?id=1744108. 
9. Kwong JC, Druce JD, Leder K. Zika virus infection acquired during brief travel to Indonesia. Am J Trop Med Hyg. 2013;89(3):516-7. http://dx.doi.org/10.4269/ajtmh.13-0029 PMID:23878182

10. Foy BD, Kobylinski KC, Chilson Foy JL, Blitvich BJ, Travassos da Rosa A, Haddow AD, et al. Probable non-vector-borne transmission of Zika virus, Colorado, USA. Emerg Infect Dis. 2011;17(5):880-2. http://dx.doi.org/10.3201/eid1705.101939 PMID:21529401

11. Zammarchi L, Stella G, Mantella A, Bartolozzi D, Tappe D, Günther S, et al. Zika virus infections imported to Italy: clinical, immunological and virological findings, and public health implications. J Clin Virol. 2015;63:32-5. http://dx.doi. org/10.1016/j.jcv.2014.12.005 PMID:25600600

12. ProMED-mail. Undiagnosed illness - Brazil (02): Zika virus confirmed. Archive Number: 20150515.3364149 Published Date: 2015-05-15 16:53:35.

13. Centers for Disease Control and Prevention (CDC). Travelers Health. Zika in Brazil. Atlanta: CDC. [Accessed 10 Jun 2015]. Available from: http://wwwnc.cdc.gov/travel/notices/watch/ zika-brazil

14. World Health Organization. Global strategy for Dengue control and prevention 2012-2020. 2012.

15. Pan American Health Organization. Number of Reported Cases of Chikungunya Fever in the Americas, by Country or Territory 2013-2014. Updated 15 May 2015.

16. Roth A, Mercier A, Lepers C, Hoy D, Duituturaga S, Benyon $\mathrm{E}$, et al. Concurrent outbreaks of dengue, chikungunya and Zika virus infections - an unprecedented epidemic wave of mosquito-borne viruses in the Pacific 2012-2014. Euro Surveill. 2014;19(41):20929. PMID:25345518

17. Oehler E, Watrin L, Larre P, Leparc-Goffart I, Lastère S, Valour $F$, et al. Zika virus infection complicated by Guillain-Barre syndrome--case report, French Polynesia, December 2013. Euro Surveill. 2014;19(9):20720. PMID:24626205

18. European Centre for Disease Prevention and Control (ECDC). Rapid Risk Assessment. Zika virus infection outbreak, Brazil and the Pacific region. 25 May 2015. Stockholm: ECDC.

Available from: http://ecdc.europa.eu/en/publications/ Publications/rapid-risk-assessment-Zika\%2ovirus-southamerica-Brazil-2015.pdf

19. Rezza G, Nicoletti L, Angelini R, Romi R, Finarelli AC, Panning $M$, et al.; CHIKV study group. Infection with chikungunya virus in Italy: an outbreak in a temperate region. Lancet. 2007;370(9602):1840-6. http://dx.doi.org/10.1016/S01406736(07)61779-6 PMID:18061059

20. Delisle E, Rousseau C, Broche B, Leparc-Goffart I, L Ambert G, Cochet $A$, et al. Chikungunya outbreak in Montpellier, France, September to October 2014. Euro Surveill. 2015;20(17):21108.

21. Grandadam M, Caro V, Plumet $S$, Thiberge JM, Souarès $Y$, Failloux $A B$, et al. Chikungunya virus, southeastern France. Emerg Infect Dis. 2011;17(5):910-3. http://dx.doi.org/10.3201/ eid1705.101873 PMID:21529410 